Article

\title{
Community Engagement in UNESCO Biosphere Reserves and Geoparks: Case Studies from Mount Hakusan in Japan and Altai in Russia
}

\author{
Aida Mammadova ${ }^{1, *(\mathbb{D}}$, Aleksandr Redkin ${ }^{2}$, Tatiana Beketova ${ }^{3}\left(\mathbb{D}\right.$ ) and Christopher D. Smith ${ }^{4}(\mathbb{C}$ \\ 1 Organization of Global Affairs, Kanazawa University, Kanazawa 921-1192, Japan \\ 2 Department of Recreational Geography, Tourism and Regional Marketing, Altay State University, \\ Barnaul 656049, Russia; redkin.ag@yandex.ru \\ 3 Territory Development and Educational Tourism, Altaisky Biosphere Reserve, Gorno-Altaysk 649000, Russia; \\ vdovina-ta@mail.ru \\ 4 Smith Custom Editing, Kanazawa 920-1156, Japan; chris@smithenglish.jp \\ * Correspondence: mammadova@staff.kanazawa-u.ac.jp
}

check for updates

Citation: Mammadova, A.; Redkin,

A.; Beketova, T.; Smith, C.D.

Community Engagement in UNESCO Biosphere Reserves and Geoparks: Case Studies from Mount Hakusan in Japan and Altai in Russia. Land 2022, 11, 227. https:/ /doi.org/ 10.3390/land11020227

Academic Editors: Margaret Brocx and Vic Semeniuk

Received: 7 January 2022

Accepted: 28 January 2022

Published: 3 February 2022

Publisher's Note: MDPI stays neutral with regard to jurisdictional claims in published maps and institutional affiliations.

Copyright: (C) 2022 by the authors. Licensee MDPI, Basel, Switzerland. This article is an open access article distributed under the terms and conditions of the Creative Commons Attribution (CC BY) license (https:// creativecommons.org/licenses/by/ $4.0 /)$.

\begin{abstract}
UNESCO's Man and the Biosphere Programme (MAB) and the International Geoscience and Geoparks Programme (IGGP) are two themes in UNESCO's Natural Science Sector. Biosphere Reserves of the MAB Programme are more focused on building international, regional, sub-regional, and ecosystem-specific cooperation as "learning places" for sustainable development with a focus on biodiversity. The IGGP supports research and capacity development in Earth Sciences and comprises two sub-programmes: the International Geoscience Programme (IGCP) and the UNESCO Global Geoparks Programme (UGGP). UNESCO Global Geoparks (UGGps) use a bottom-up approach to engage local communities in capacity building, via tourism development, with the common goal of promoting and protecting the area's geological and cultural heritage. Here, we present the results of comparing local involvement from two case studies from Japan, the Mount Hakusan Biosphere Reserve and the National Mount Hakusan Tedori-river Geopark, along with two case studies from Russia, the Altaisky Biosphere Reserve and the regional Geopark Altai. In this study, we found more involvement by local community members in the Geopark than in the Biosphere Reserve in Japan. The Russian case studies show a complete opposite result with more involvement of local communities in the BRs, and less participation in Geopark management. The purpose of this project was to provide information to improve local involvement in both Japanese and Russian Biosphere Reserves and Geoparks through changes in education and management styles.
\end{abstract}

Keywords: geoparks; biosphere reserves; local communities; management; regional sustainable development

\section{Introduction}

UNESCO's Natural Science Sector has Secretariats for two Programmes that deal with designations of sites with significant international values. These two Programs are: International Geoscience and Geoparks Programme (IGGP) [1] and the Man and the Biosphere (MAB) Programme [2]. These two programmes provide designations internationally, such as UNESCO Biosphere Reserve (BR) and Global Geopark (UGGp). Both designations are also complementary to other designations by UNESCO, such as World Heritage Sites. BRs and UGGps are natural sites recognized by UNESCO to conserve the world's biological, geological, and cultural diversity, and to promote sustainable economic development for present and future generations. In the case of UGGP, the main focus is on sustainable use and conservation of geological heritage, and in terms of BR, biodiversity is the main focus.

The concept of BRs was created in 1976 by the UNESCO's Man and the Biosphere (MAB) Programme, as sites where human-nature interactions are tested, refined, and demonstrated, and where the objectives of the MAB program are implemented. BRs are like 
scientific laboratories that promote solutions reconciling the conservation of biodiversity with its sustainable utilization [3]. They are special places for testing interdisciplinary approaches to understand and manage changes and interactions between social and ecological systems, including conflict prevention and the management of biodiversity. All BRs have had three main objectives: conserving biodiversity, which aims to preserve landscapes, ecosystems, species, and genetic variations; promoting sustainable development by fostering social, cultural, and ecologically sustainable economic development to benefit local peoples; and supporting research, monitoring, and education $[4,5]$. The MAB Program launched the World Network of Biosphere Reserves and, as of 2021, the number of BRs has reached 727 in 131 countries [6].

GP refers to a territory that has a particular geological heritage site of geological significance and a sustainable development strategy for territorial protection [7]. The first concept of a GP was developed in Europe in 1989 [8], and in 2004, UNESCO supported the creation of the Global Geoparks Network (GGN) and later in 2015 created a new label called “UNESCO Global Geoparks". UNESCO Global Geoparks are single, unified, geographical areas where sites and landscapes of international geological significance are managed through the holistic concept of protection, education, and sustainable development [9]. As of 2021, 169 UNESCO Global Geoparks in 44 countries are recognized. Geoparks provide information on the history of the Earth, and they are also the keepers of archaeological, ecological, historical, and cultural values, all of which make them play a significant role in education, science, and cultural and socio-economic development.

Brief descriptions of both programmes are shown in Table 1. In some cases, when the area has overlapping international designations of both BR and UGGp, then the sites are called Multi-Internationally Designated Areas (MIDAs) [10]. Both BRs and UGGps are designed to combine conservation with sustainable development while involving local communities and encouraging national governments and local communities to recognize significantly important areas to contribute to reasonable utilization of their natural resources for current and future generations. They examine the positive interaction between people and nature over a long period of time and are functioning as learning sites for sustainable development [11-13].

Table 1. Differences between UNESCO Designated Biosphere Reserve and UNESCO Global Geopark.

\begin{tabular}{|c|c|c|}
\hline & Biosphere Reserve & Global Geopark \\
\hline Goal & $\begin{array}{l}\text { Harmony between protecting } \\
\text { biodiversity and utilizing it in a } \\
\text { sustainable manner }\end{array}$ & $\begin{array}{l}\text { Protecting geological sites and } \\
\text { related assets and developing } \\
\text { them in a sustainable manner }\end{array}$ \\
\hline UNESCO Programme & Man and the Biosphere & Global Geopark \\
\hline Origin & 1976 & 2015 \\
\hline Territories & $\begin{array}{l}\text { Terrestrial, marine, and } \\
\text { coastal ecosystems }\end{array}$ & $\begin{array}{l}\text { Single or unified geographical } \\
\text { areas with international } \\
\text { geological significance }\end{array}$ \\
\hline Number of Sites & 727 in 131 countries & 169 in 44 countries \\
\hline Priority Focus & Biodiversity & Geological features and terrain \\
\hline Three objectives & $\begin{array}{c}\text { Conservation } \\
\text { Sustainable development } \\
\text { Logistic support }\end{array}$ & $\begin{array}{c}\text { Protection } \\
\text { Education } \\
\text { Sustainable development }\end{array}$ \\
\hline
\end{tabular}

While the purpose of BR and UGGp is different, there are some notable similarities: (1) conservation of the regional nature and natural heritage; (2) encouragement of scientific research and education for regional nature; and (3) encouragement of the local community and economy though science-based sustainable development using regional, natural resources [14]. One of the main purposes that links those two programmes together is the participation and involvement of local communities in the economic activities for the 
regional development. Economic, social, and environmental are the three dimensions of sustainable development that are supported by UNESCO, the 2030 Agenda, and the Sustainable Development Goals (SDGs) [15]. To achieve sustainable development, the active engagement and participation of communities and sectors are needed inside the geoscience community [16] and ecosystem management [17]. Through the involvement of local communities, both programmes can contribute to the development of regional tourism, create jobs, and generate a stable income for people in rural areas [18], which are common goals of both programs [19].

Even though the programs have similarities, approaches to sustainable management and the involvement of local communities are different around the world. Some communities use more "bottom-up" approaches, where almost all activities and decision-making are conducted through the involvement of local people and communities. Other countries have more "top-down" implementations for the management of BR and GPs, where local governments or authorities are managing and regulating the programme. The differences between such kinds of management may depend on the historical relationship between government and local communities, perceptions on nature protection, and attitudes towards the economic gain from nature [20].

Additionally, until now, protected areas were very research-oriented and focused mainly on either biodiversity or geodiversity monitoring to prevent the loss of natural resources, and often overlooked the needs of the local communities and populations [21]. The demand for scientific and data-based knowledge played the main role in geodiversity and ecosystem management [22], rather than the engagement of local communities. In Japanese and Russian UNESCO BRs and UGGps, not so many studies exist that evaluate the relationship between the programmes and local communities. Therefore, the two main objectives of this study were to compare and evaluate the level of involvement of local communities in BRs and UGGps between the two countries, and to find the main factors that influence the difference in levels of involvement. In this study, we chose Japanese and Russian cases to make a comparative analysis of the differences in management systems, designation processes, and possibilities for regional sustainable development through the engagement of local communities.

\section{Methods}

In Japan, we studied the Mount Hakusan Biosphere Reserves (MHBR) and the National Mount Hakusan Tedori-river Geopark (MHTGP). In Russia, the Altai Biosphere Reserves (ABR) and the Regional Altai Geopark (AGP) were the subjects of our study. Both Japanese and Russian Geoparks are aspiring UNESCO Global Geoparks. To make UGGp different from those aspiring Geoparks, we will use "GP" to indicate Geoparks designated as National and Regional Geoparks. The selection of the two BRs and GPs was conducted according to the differences in the establishment, planning processes, management, and roles of local communities in each program, along with how long they have been functioning as BR and GPs. The similarities were that each BR and GP in each country had overlapping territories (MIDA), both GPs were aspiring UGGps still not recognized by UNESCO, and both BRs have shown similarities in demographic situations, livelihoods, and geographical location.

The data concerning both BRs and GPs in each country were collected separately. First, in 2017-2018, we analyzed the Japanese and Russian cases through a desktop literature review, collecting information from different resources, such as BR and GP application reports, including relevant literature, primary sources, and related articles and publications. Some information was provided by the BR and GP staff. The data collection was focused on the management systems of protected areas, the role of communities in promoting regional development in each $\mathrm{BR}$ and GP, and reviewing the sources from the legislative and policy statements.

Furthermore, field work was conducted by visiting both BRs and GPs in Japan and Russia: in 2018, the MHBR and the MHTGP in Japan; and, in 2019, the ABR and the 
AGP in Russia. The information was collected through formal and informal interviews with the managers, directors, community leaders, local villagers, and private enterprises working inside BRs and GPs, and relevant authorities of each country. The interviews were conducted personally or via web-based telecommunication services in a semi-structured way [23]. The interviews were mainly focused on the BR and GP history, management, organizational structure, and community involvement in bio- and geo-conservation and regional economic development.

\subsection{Case Studies in Japan and Russia}

\subsubsection{Mount Hakusan Biosphere Reserve (Japan)}

The MHBR, facing the Sea of Japan, is one of the first designated UNESCO BRs in Japan (Figure 1). Towering over the BR is a volcano with eight craters near the summit called Mount Hakusan (2702 m elevation). The summit landscape is filled with lake and pond habitats such as the Senjaga, which stays frozen all year round.

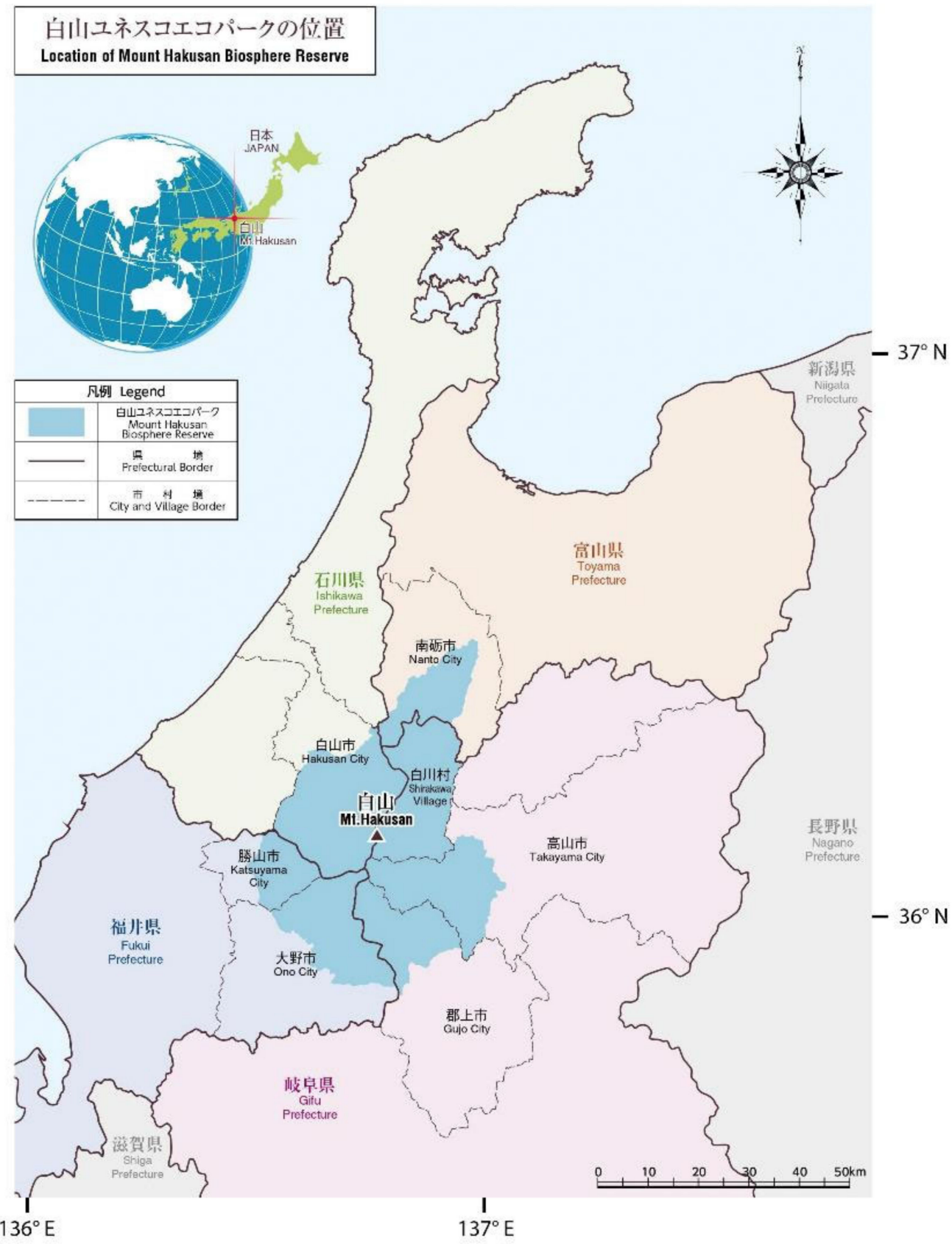

Figure 1. Location of the Mount Hakusan Biosphere Reserve between four prefectures. 
There are distinct altitude zonations of the vegetation within the park that range from warm temperate to alpine zones. The summit includes alpine flora such as Anemone narcissiflora and Orchis aristate along with strands of creeping pine. Unique 'Altherbosa' (communities with tall herbaceous plants) can be found persisting in the 'snow slip' lands and non-woodland steep alpine screen slopes. The Tedori river runs near the base of the mountain. Here, there are coniferous forests including firs (Abies mariesii), pines (Pinus aristata), and Japanese cedar (Cryptomeria japonica). There are also deciduous forests and woodlands [24].

The foothills of the mountain are very hilly, and the mountainous areas are settled by local villagers. The population is more than 17,000, and the total territory spans $1993 \mathrm{~km}^{2}$ [25]. Historically, the area was first designated as Hakusan National Park, which expanded between four Prefectures (Ishikawa, Toyama, Gifu, and Fukui) [26]. In 1980, the protected territory of the National Park was designated as the UNESCO Mt. Hakusan Biosphere Reserve with only core and buffer zones. However, this designation was conducted in a top-down manner by local authorities and had no recognition among the local villagers. For more than 30 years, the designation stayed dormant without any practical municipal management and was unrecognized between local communities. The real work on the MHBR started in 2010 when Japan was challenged by the MAB's "Seville Strategy" for Biosphere Reserves [27] declaring the expansion of the BRs to include the transition zones to promote regional sustainable development. This strategy required the inclusion of local communities in all management processes and utilization of natural resources by the locals. The locals' involvement started in 2012 when a dialog was created between the governments of the four prefectures and seven municipalities. Later, the local MHBR Council was created, and a final agreement was made to apply for an extension of the transition zone, which included the territories with human settlements.

\subsubsection{Mount Hakusan Tedori-River Geopark (Japan)}

Designated as a Japanese National Geopark in 2011, the Mount Hakusan Tedori-river Geopark is located in Ishikawa Prefecture on the west coast of Japan. The total area is $754.93 \mathrm{~km}^{2}$ and encompasses all of Hakusan City. It is comprised of Mt. Hakusan $(2702 \mathrm{~m}$ elevation) and the Tedori River basin, which runs from the summit of the mountain to the Sea of Japan. In the mountains, the temperature averages around $2{ }^{\circ} \mathrm{C}$ and lower. The highest peak, Mt. Hakusan, along with the surrounding area is one of the world's highest snowfall areas. Flowing from the summit, the Tedori river is one of the steepest rivers in the world, having an average gradient of $1 / 27$. At the end of the river, near the plains of the Sea of Japan, the climate is relatively mild with temperatures around $13-14{ }^{\circ} \mathrm{C}$ and 2000 to $3000 \mathrm{~mm}$ of annual precipitation. The flora and fauna of the mountain are considered some of the best in Japan. There exists a high density of wildlife, such as birds and mammals. Located in the westernmost alpine area of Japan, Mt. Hakusan has the westernmost distribution of many alpine species. This diverse wildlife and plant life are protected through the Mount Hakusan Biosphere Reserve and the Hakusan National Park [28].

A number of geosites (geospots) have been identified along the river flow and the entire GP is divided into three areas: the mountain and snow area; the river and gorge area; and the sea and alluvial fan area (Figure 2). In addition, this GP has a wide distribution of strata with paleontological significance from the prehistoric era, which includes the Kuwajima fossil bluff (a national natural monument), making it one of the leading Mesozoic fossil sites in Japan [29]. 


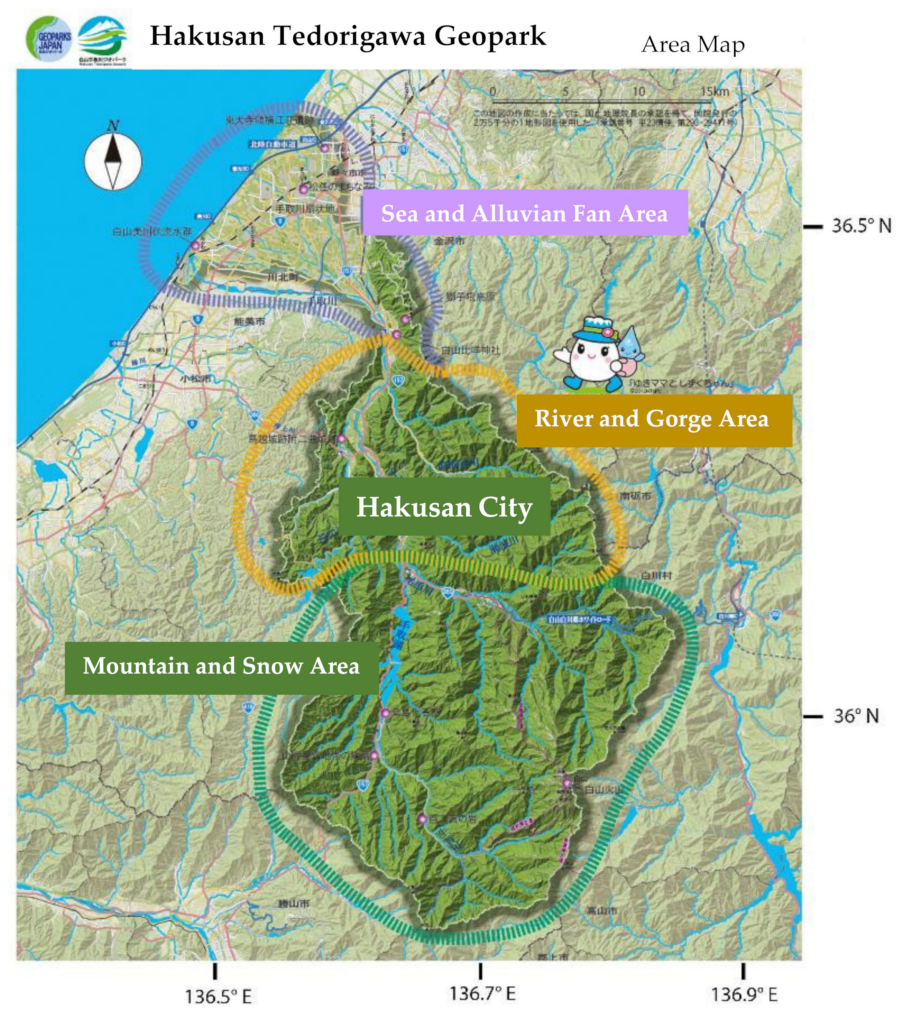

Figure 2. Entire territory of Hakusan City, designated as the National Mount Hakusan Tedori-river Geopark (Map provided by MHTGP Promotion Council).

\subsubsection{Altaisky Biosphere Reserve (Russia)}

The Altaisky State Nature Reserve was founded in 1932, with a total territory of 871,206 hectares. It is located in the north-eastern part of the Altai Republic (Russia). The territory of the ABR includes five physico-geographical areas of three natural provinces. Almost all natural zones of the Altai Mountains are distinguished in the spectrum of altitudinal zonation: taiga low mountains and mid mountains, subalpine and alpine meadow middle mountains and high mountains, tundra-steppe high mountains, tundra middle mountains and high mountains, and glacial high mountains. Forests occupy $34 \%$ of the total area of the core zone. The variety of natural and climatic zones of the ABR creates the exceptionally rich species composition of the flora and fauna on its territory. More than 2050 representatives of flora, 333 species of birds, 70 species of mammals, 16 species of fish, 2 species of amphibians, and 6 species of reptiles can be found on its territory. The reserve also includes four important bird areas [30]. The central estate of the reserve is located in the village of Yaylyu, and the main office is in the city of Gorno-Altaisk, the capital of the Altai Republic. The Reserve has a unique, specially protected natural territory of Russia, a UNESCO World Natural Heritage Site that includes part of Lake Teletskoye. In 2009, after a decision of the 21st session of the International Coordinating Council of the UNESCO Man and the Biosphere Programme, the Altai Reserve was included in the World Network of Biosphere Reserves. The total area of the ABR is more than $35,000 \mathrm{~km}^{2}$, with a transition zone that includes two administrative districts-Turochaksky and Ulagansky. In addition to its primary task of the preservation of the protected areas, the ABR has undertaken responsibilities to promote sustainable development and ensure the socio-economic stability of the local community [31].

The protected areas of the Altai Republic are closely related to the protected areas of the neighboring regions of Russia and form the so-called Altai-Sayan ecoregion, which is included in the "Global-200" list (the World Wildlife Fund's Living Planet Campaign), a list of untouched or less changed ecoregions of the world in which $90 \%$ of the planet's biodiversity is concentrated. An example of the ABR can be seen on the map shown in 
Figure 3). Clusters of two other State Reserves-Khakassky (The Republic of Khakassia) and Ubsunurskaya Hollow (The Republic of Tuva) - adjoin the borders of the ABR. All three protected areas have a biosphere status at the national level and form a single, specially protected area-an interregional biosphere reserve.

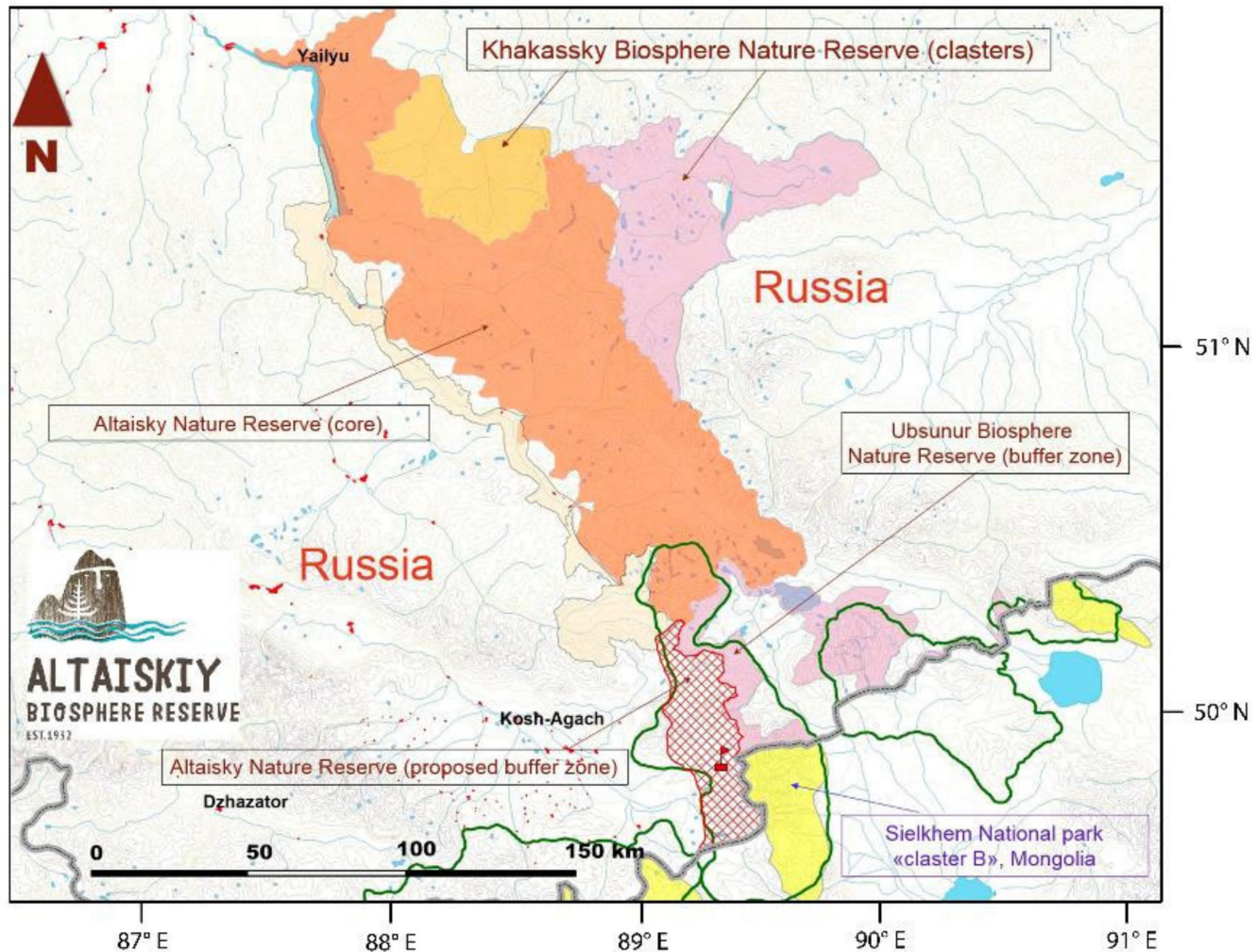

Figure 3. Altaisky Biosphere Reserve with other surrounding protected areas.

\subsubsection{Geopark Altai (Russia)}

The Geopark Altai, a Regional Geopark, with a total area of over $14,500 \mathrm{~km}^{2}$, is located in the center of the Altai Republic (south-east of Western Siberia) and stretches along the Chuya and Katun Rivers and almost reaches the borders with Mongolia. Due to its location, two clusters are distinguished in the geopark— "Chuisky" and "Teletsky" - covering its lower part and Lake Teletskoye to the Korbu waterfall (Figure 4). An important feature of the Altai Geopark is its geological and geographical diversity. Rocks of the Precambrian age and almost the whole Phanerozoic (Paleozoic, Mesozoic, and Cenozoic eras) come to the surface here. More than 60 geological and geographical objects (geosites) are included in the Geopark. Some types of objects include structural geology, lithology, mineralogy, geomorphology, karst, glaciation (modern and ancient), and objects formed by exogenous processes [32]. On the territory of the geopark, there are unique hydrological objects: Teletskoye Lake and the Chuya, Bashkaus, and Chulyshman Rivers. 


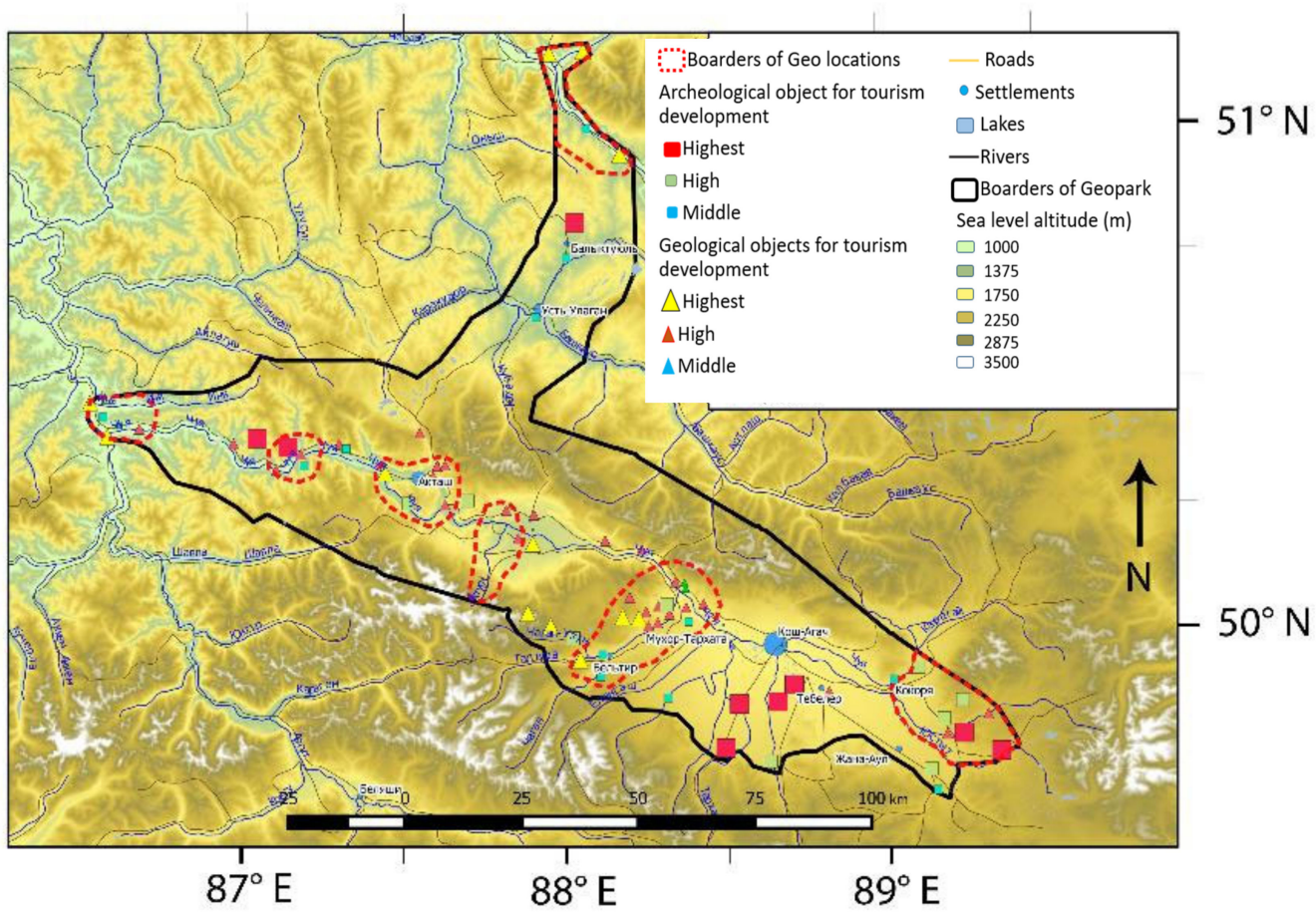

Figure 4. Entire territory of Geopark Altai.

The archaeological monuments belong to at least three historical periods: the NeolithicEneolithic, the Scythian epoch, and the Turkic epoch. The monuments were left by a population different in their anthropological type, language, culture, level of development, and other features from the modern inhabitants of the region. Thus, the territory included in the geopark can be positioned as a "Crossroads of Worlds" between different groups of Inner Asian populations from the Stone Age to the ethnographic time. On the territory of the Geopark live people of many nationalities, each of which has its own features of life and culture. These are various tribes of Altai (indigenous people)-Telengits, Tubalars, and Chelkans-as well as Kazakhs, Russians, and other peoples.

\section{Results}

\subsection{Management of the MHBR and the MHTGP in Japan}

The territories of both the MHBR and the MHTGP have some overlapping areas (Figure 5).

Both programmes are managed by the local municipality of Hakusan City. The activities of local communities for sustainable resource utilization are allowed within those territories. For the management of the two programmes, the local government of Hakusan City has created two divisions for each programme: one is the Mount Hakusan Biosphere Reserve Council, and the other is the Hakusan Tedori-river Geopark Promotion Council. The MHTGP Promotional Council was created to develop this regional geopark into a UNESCO Global Geopark. In 2021, the MHTGP was selected by the Japanese Ministry of Education, Culture, Sports, Science, and Technology as an Aspiring UNESCO Global Geopark.

Currently (for 2022), the Mayor of Hakusan City is acting as the council chair of both programmes, and the secretariat is based at the Hakusan City Office. The Ministry of the Environment, which is responsible of the management of Hakusan National Park, is also associated with both councils, and the Ministry of Education, Culture, Sports, Science, and Technology is associated with the MHBR. Both councils are acting according to the concepts of the international initiatives aiming for sustainable development. In addition, both councils emphasize the importance of not only protecting but also utilizing the natural resources of Mt. Hakusan in a sustainable manner by involving local citizens 
and enterprises. The MHTGP Promotion Council promotes those activities through the development of geotourism and has more bottom-up approaches. This council, together with local communities, has developed programs with different geo-tours, and local people work as guides authorized by the council. Tourism activities are supported through the promotion of local goods made inside the GP, animated characters, website creation, and the dissemination of information on social media channels [33]. Additionally, the entire City of Hakusan has been working on Sustainable Development Goals using geopark activities and was designated by the Japanese Government as one of the "Future Cities for SDGs".

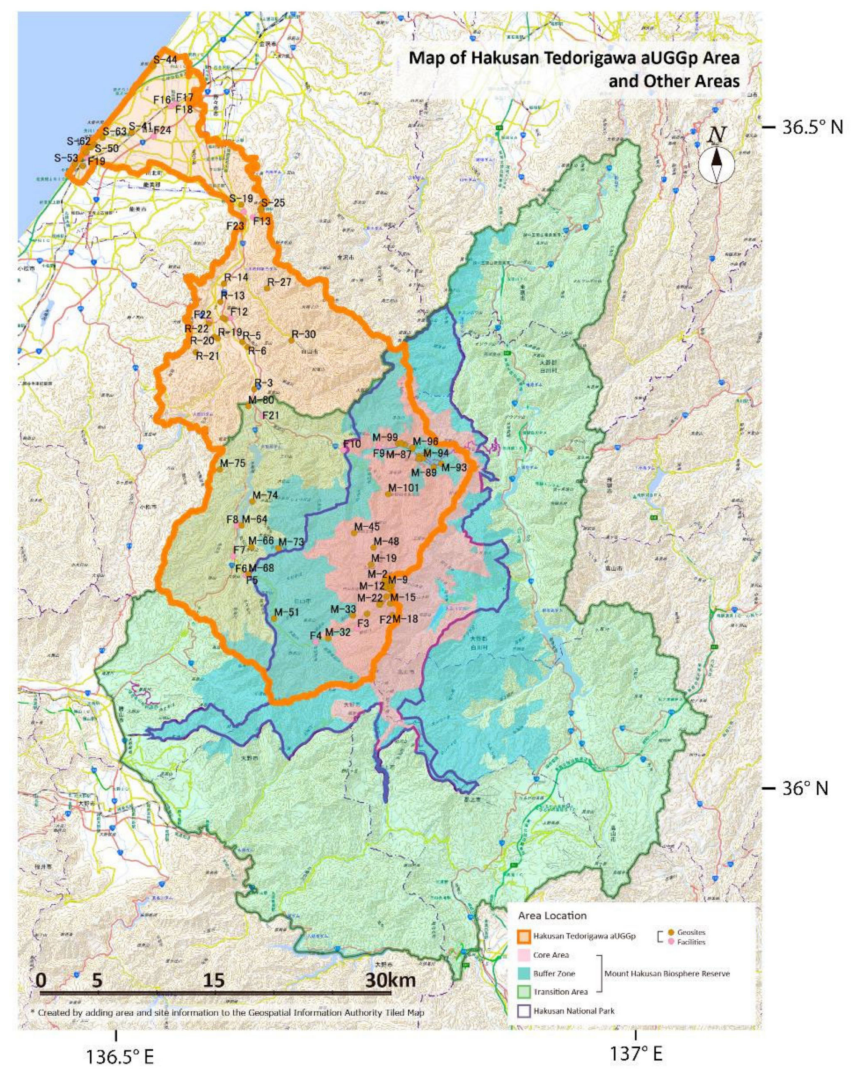

Figure 5. Overlapping territories between the Mount Hakusan Biosphere Reserve (green line) and the aspiring UNESCO Global Geopark MHTGP (orange line). Capital letters with numbers show geosites. Map provided by MHTGP Promotion Council.

The management and government of the MHBR with the involvement of local communities are more complicated as it has a multi-governmental approach between seven municipalities and four prefectures and the decision-making process requires communication between all municipalities. The MHBR council was created in 2014 with 12 members as an official organization to conduct the future management of the MHBR. The council also has an executive board with two working groups (WGs) and an academic group [25]. However, the management and operation plan was only formulated in 2018. Even though local people have lived and worked in these areas for generations, they still lack awareness of the designation and objectives of the BRs. In 2019, the MHBR authorities decided to create the first local workshop and bring together all villagers from different municipalities to share ideas and good practices. To involve more local villagers, a second workshop was created in 2021, with the topic of "Mount Hakusan BR friends' connection through Food", at which more than 23 participants from 4 prefectures presented local food products specific to each region. 


\subsection{Management of the ABR and the AGP in Russia}

The present administration of the $\mathrm{ABR}$, apart from protecting and presevering the natural resources of the $\mathrm{BR}$, is also building a strong relationship and partnership with diverse stakeholders, the local and regional government, NPOs, etc. The administration of the ABR gives an important role to the local population in governing the development of the Reserve. In 2007, local community councils were created in the Reserve villages Yailu and Bele (located in the core zone of the BR). In February of 2014, in Yailu village a territorial public self-governing body called "Reserve's Village" was registered. The joint activity of the ABR and the territorial public self-governing body "Reserve's Village" helps to resolve issues such as the collection and disposal of garbage, the observation of nature in the reserve, and the participation of local residents in tourism.

One of the examples of partnership in the management and development of the ABR (transition zone) is the non-profit organization "Teletskoye Lake Council', which was established in 2009 by the local communities. The main goal of the "Teletskoye Lake Council" is to create conditions for the preservation of a unique UNESCO World Heritage SiteTeletskoye Lake-in compliance with environmental and nature-protecting requirements and the socio-economic development of the territory. The "Teletskoye Lake Council" has become a wide platform for communication between and the collaboration of various stakeholders in the Teletskoye Lake area, and allows them to carry out their responsibilities of the conservation and development of the UNESCO World Heritage Site [34].

The ABR, in providing an opportunity to some local and indigenous communities for self-management and governance, has shown a successful bottom-up approach, which was emphasized in the Lima Action Plan and the MAB Strategy 2015-2025.

Since 2014, discussions on the creation of the Altai Geopark (AGP) have been conducted at the ministry and academic levels [35] inside the Altai Republic. According to the discussions and a government decree, in 2015, a regional "Altai Geopark" was created, uniting unique natural sites with geological objects, cultural and historical landscapes, within three administrative districts: Ongyday, Ulagan, and Kosh-Agach. The Altai Biosphere Reserve overlaps with the territory of the Altai Geopark within the Ulagan Municipality (District) and the Teletskoye Cluster. Geological objects of the AGP make these territories very popular destinations for tourists, and the local government is expecting that the recognition of this territory as a geopark will contribute to sustainable regional development and improve the economic conditions of the local communities. However, because the concept of geopark is still new, and due to the issues with the management of big territories, the local AGP has shown very little progress in the involvement of local communities. The involvement of local communities can only be seen in the Teletskoye cluster, where some areas of the AGP overlap with the ABR. The number of tourists is increasing annually, however, and the tourism is managed differently within different clusters. The local community is more involved in geopark activities in the "Teletskoye" cluster, primarily due to the established cooperation between the ABR and the Teletskoye Lake Council. The council took responsibility for environmental protection and the development of tourism activities in the part of Teletskoye Lake that is not part of the BR, but is part of the GP. Local residents organize and conduct excursions to Teletskoye Lake and develop infrastructure for accommodation and meals for tourists; all these initiatives are supported by the management of the ABR. The "Chuysky" cluster that has no partnership with the BR is developing through the initiatives of local communities and with the support of local universities.

Differences between the Japanese and Russian cases of BRs and GPs in terms of territorial area, governance, management, and involvement of local communities are shown in Table 2. The clearest and most relevant similarities between the Japanese GP and the Russian BR can be seen in the Management and Level of locals' involvement in management process rows of the table. 
Table 2. Differences between the Russian ABR and AGP, and the Japanese MHBR and MHTGP.

\begin{tabular}{|c|c|c|c|c|}
\hline \multirow{2}{*}{$\begin{array}{l}\text { Country } \\
\text { Program }\end{array}$} & \multicolumn{2}{|c|}{ Japan } & \multicolumn{2}{|c|}{ Russia } \\
\hline & $\begin{array}{l}\text { Mount Hakusan Biosphere } \\
\text { Reserves (MHBR) }\end{array}$ & $\begin{array}{c}\text { Mount Hakusan } \\
\text { Tedori-river Geopark } \\
\text { (MHTGP) }\end{array}$ & $\begin{array}{l}\text { Altai Biosphere Reserve } \\
\text { (ABR) }\end{array}$ & Altai Geopark (AGP) \\
\hline UNESCO Designated & Yes & Aspiring & Yes & Aspiring \\
\hline Year of origin & 1980 & 2011 & 2009 & 2015 \\
\hline Territory & $1993 \mathrm{~km}^{2}$ & $754 \mathrm{~km}^{2}$ & $35,000 \mathrm{~km}^{2}$ & $14,500 \mathrm{~km}^{2}$ \\
\hline $\begin{array}{c}\text { Overlapping areas } \\
\text { between Biosphere } \\
\text { Reserve and Geopark }\end{array}$ & \multicolumn{2}{|c|}{ Yes } & \multicolumn{2}{|c|}{ Yes } \\
\hline Main Features & $\begin{array}{c}\text { Biodiversity and cultural } \\
\text { diversity }\end{array}$ & $\begin{array}{l}\text { Geological, } \\
\text { Geographical, } \\
\text { Hydrological, } \\
\text { Archeological }\end{array}$ & $\begin{array}{l}\text { Biodiversity, cultural and } \\
\text { landscape diversity }\end{array}$ & $\begin{array}{c}\text { Geological, } \\
\text { Geographical, } \\
\text { Hydrological, } \\
\text { Archeological, } \\
\text { and Ethnographical } \\
\text { diversity }\end{array}$ \\
\hline Governance & $\begin{array}{l}\text { Multiple municipalities } \\
\text { and prefectures }\end{array}$ & Single municipality & $\begin{array}{c}\text { Multiple and } \\
\text { transboundary units }\end{array}$ & Single region \\
\hline Management & Local authorities & $\begin{array}{l}\text { Synergistic with local } \\
\text { authorities and } \\
\text { communities }\end{array}$ & $\begin{array}{l}\text { Synergistic with local } \\
\text { authorities and } \\
\text { communities }\end{array}$ & Local authorities \\
\hline $\begin{array}{l}\text { Level * of locals' } \\
\text { involvement in the } \\
\text { management process } \\
\left({ }^{*} \text { The levels were }\right. \\
\text { evaluated as high if more } \\
\text { than } 5 \text { interviewers } \\
\text { confirmed community } \\
\text { involvement.) }\end{array}$ & Low & High & High & Low \\
\hline Community Council & Does not exist & Does not exist & Created & Does not exist \\
\hline
\end{tabular}

\section{Discussion}

Japan and Russia have different approaches inside BRs and GPs in the management approaches and involvement of local communities for regional development. GPs in Japan have a higher degree of involvement of local communities than Russian GPs. In contrast, Russian BRs have shown more active local engagement than their Japanese counterparts, where regulations by the local authorities are still dominant. The differences between such kinds of management may depend on the historical relationship between government and local communities, perceptions of nature protection, and attitudes towards the economic gain from nature [20].

\subsection{Japanese Case Studies}

We have seen in the MHBR that the designation of the territory as a UNESCO Biosphere Reserve caused no significant community engagement. This is due to the fact that the designation process was conducted by the local authorities and government and the locals were not even informed about it. Furthermore, the concept of BRs was completely unfamiliar to them. Almost all BRs in Japan are designated within already existing protected territories, and in all cases those areas encompassed protected territories of National Parks. The MHBR was also designated within the territory of a National Park, and for the locals, the concept of National Park was much more dominant and recognizable. The system of National Parks is the most recognizable and extensive system in Japanese nature conservation. One of the main distinguishing features of Japanese National Parks is that even if the territory is protected, it belongs to the local people, and it is not established as state-owned land, like in many Russian cases. The land is not "set aside" for nature conservation [36,37], but rather it is utilized and owned by the local communities. Even though Japan was the first country in Asia to adopt the idea of National Parks from the 
United States in 1930 [38], this concept was not purely about nature conservation, but was rather economic development oriented with the promotion of tourism and recreation. Japanese National Parks have shown difficulties in finding a balance between conservation and development and have also had issues such as less public participation in decisionmaking processes [39]. We can assume that for, the local communities, the designation of National Parks into UNESCO Biosphere Reserves did not produce any significant changes for following reasons: (1) they were not involved in the designation process; (2) they were not familiar with the concept of BRs; and (3) the concept of National Parks was more dominant.

In terms of the GP, since 2004, the interest in geoparks has increased among Japanese geologists and some municipalities who were conducting geological surveys. Researchers in the geological sciences started to actively cooperate with local authorities and private organizations. In 2007, they created the Japanese Geopark Liaison Council [40], and, later, the Japan Geopark Committee (JGC) was established with the involvement of National Ministries, the Geological Survey of Japan (AIST), and several other agencies. The JGC nominated the first three Global Geoparks [41] and created the Japanese Geoparks Network (JGN) in 2009. The number of academic researchers participating in geopark activities increased and frequent article and newspaper publications helped the concept of geopark spread very fast among the general public. Due to the intensive and constant activities since 2016, the Japanese National Commission for UNESCO officially recognized the JGN as a Japanese National Committee and provided the authority to conduct an application for new candidates who would like to be recognized as UNESCO Global Geoparks as well as Japanese National Geoparks.

Under the terms of UGGp accreditation, it is crucial for all GPs that sustainable management is conducted with the involvement of the local communities, and the JGC together with the JGN carries out the processes for the certification of local guides. Every four years, a re-evaluation process is carried out to improve the activities of the local guides. These concepts contributed significantly to the creation of a new form of tourism, so-called "geo-ecotourism", which has become very popular in Japanese geoparks and is used as a new source of income for the local communities [42]. Geo-ecotourism aims to develop human resources in both "geo" (geological) and "eco" (ecosystem) terms and by using ecological approaches and conducting touristic activities with scientific explanations. Special training, seminars, and certification processes to increase the number of local guides are constantly being conducted within each of the National and Global Geoparks of Japan.

Due to the synergy between top-down and bottom-up approaches, the MHTGP and Japanese geoparks are considered to have very successful management systems since they include collaboration between local residents, scientists, local authorities, and private organizations [43]. Many educational programs are carried out for local people in disaster management and geological sciences [44]. Japan is an island country, located on the boundaries of tectonic plates, so most Japanese geoparks address issues relating to natural disasters, such as volcanic eruptions, earthquakes, tsunamis, and landslides. Thus, many geoparks take similar approaches to defining geo-heritage sites, which will usually address one of those natural disasters. Human life in Japan has always been subject to natural events and the processes of the ecosystem's recovery after a natural disaster. Over time, catastrophic natural events created unique landscapes, with sites of geo-heritage significance, and provided resources and opportunities for human settlements. Today, Japanese geoparks promote geotourism and provide information about the geological history of natural disasters together with the human response to ecosystem restoration and management. This coexistence of the human population with a territorial area that has significant geological activity (volcanic eruptions, earthquakes, etc.) and the ability to adapt following those disasters resulted in the creation of a region-specific culture. This was taken into consideration during the application processes of the first Japanese Global Geopark [45]. 


\subsection{Russian Case Studies}

The Russian cases showed more involvement of local communities in BR management, and less participation in GP management. We can suggest that this is related to the history of nature protection and the concept of State Reserves, which is very familiar to Russian people. The idea of nature conservation is deeply rooted in the history of Russia, and there are very strict, state-run nature protection regulations called "Zapovedniks" (Strict Scientific Nature Reserves) [46]. The concept of a Zapovednik started at the beginning of the 20th century, and later evolved into research institutions under the Ministry of Natural Resources and Environment of the Russian Federation. Zapovedniks have three main functions: (1) protecting and conserving biodiversity and ecosystems in their natural conditions; (2) conducting ecological monitoring and research; and (3) training specialists and personnel for nature conservation. At first, Zapovedniks prohibited any economic development and human activities, except for the activities of rangers and scientists. The designation of the first BRs and the inclusion of Zaopvedniks into the international network started in 1978 when the first seven Zapovedniks were designated by the MAB Programme inside the USSR (five in the present Russian Federation). After two years, in 1980, BRs became more popular among scientists and research institutions as they were able to investigate and compare the anthropogenic influence on protected territories $[47,48]$ and not just conduct research on ecosystems and biodiversity. To ease access into the Zapovedniks and to conduct research and socio-economic activities, special testing sites were created to test human-nature interactions, and those territories were called "Biosphere Polygons" (testing sites). Later, polygons were adopted by the Federal Law of Russia as "Specially Protected Natural Areas", allowing for the addition of testing sites inside the Zapovedniks not only to conduct scientific research and monitoring, but also to function as territories to implement the rational utilization of natural resources by locals [49]. However, the concept of regional socio-economical and sustainable development was only integrated into Russian BRs in 1995, after the adoption of the MAB's "Seville Strategy" for BRs [27]. The Seville Strategy functioned as a changing point for all BRs worldwide, with its declaration to promote regional sustainable development and the reasonable utilization of natural resources by locals inside BRs, and required the addition of transition zones with human settlements inside each BR, apart from core and buffer zones. After these changes, many BRs in Russia created Public Councils to include the local communities in the management of BRs, and, in the case of the ABR, we have seen the involvement of local communities in the management and decision-making processes of protected territories. The creation of the "Teletskoye Lake Council" by locals and the registration of the "Reserve's Village" as a self-governing village are two such examples.

However, in terms of Russian GPs, to date, this concept has been recognized only among scientists, and has had less recognition at the local level and in local communities. Russia has a very long history of geological research, which dates back to 1882 with the creation of the Geological Committee and its later development into the Russian Geological Research Institute [50]. Russia has a very strong background in Geological and Earth Science and is considered to be one of the leading countries in the development of Geological Sciences. However, the concept of geoparks as a platform for sustainable development is a relatively new concept, since, to date, all activities have been mainly research and science oriented. In Russia, at the regional level, there are only three geoparks. The first geopark of Russia (Bashkiria) only entered the global network of UNESCO Global Geoparks in 2019. VSEGEI [50] has highlighted three main factors that hinder the development of geoparks in Russia. The first is a lack of a legal and regulatory framework for geoparks. There is no concept of "geopark" in the Federal Russian legislation, although the law on "specially protected natural territories" allows for the designation of "other" conservation categories. The second factor is the poor awareness of the population and local authorities about how to create geoparks. Geoparks are identified with natural monuments and wildlife sanctuaries where the law prohibits economic activities. This contradicts the main criteria of a UNESCO Geopark, which, according to the Charter of the International Geoscience and 
Geoparks Programme, are economic development of the region and involvement of local residents in the geopark's organization and management. The third factor is the relative inertia of business communities, who are reluctant to invest in geopark projects, although there are many successful examples of combining environmental conservation with the development of eco and geotourism in Russia.

The whole territory of the Altai Geopark is used by the population in the process of economic activities, and the local communities' lifestyle is directly connected to the traditional use of nature [51]. However, due to climate change, globalization effects, and changes in land use, the entire territory is suffering from the regional outflow of the population with a low income. There is a need for alternative sources of income, which, while preserving the traditional way of life, would attract more people into the region. Therefore, in Altai, the local government expects that the designation of the territory as a geopark will draw attention to the problem of preserving sites of geo-heritage significance and economic development; increase the rate of tourism development; unite all land users within the geopark; and help to develop a territory management plan [52]. The aim of the regional AGP is to become a UNESCO Global Geopark. In our opinion, the programme brings hope for the sustainable development and economic stability of the local communities who suffer from low incomes and population outflows. Even though the recognition of the geopark concept remains very low among the local communities, the territory attracts tourists from all over the world due to its unique combination of geodiversity, biodiversity, and culture as well as the tangible and intangible heritage of the entire Altai Republic [32]. Infrastructural transformations in the last few decades have contributed to an increase in the tourist flow to the remote territories of the Republic, including the territory of the GP.

\section{Conclusions}

In comparing community engagement at the Japanese and Russian sites, we found three main factors that influence the level of local involvement: (1) the historical relationship between government and local communities; (2) perceptions of nature protection; and (3) attitudes towards the economic gain from nature. Although the historical relationships cannot be changed moving forwards, increasing the education of residents may potentially alter their perceptions about protecting nature and their attitudes towards benefiting economically from BRs and GPs. It may be possible to increase the promotion of Japanese BRs and Russian GPs through programmes and management approaches that are similar to those of their counterparts: Japanese GPs and Russian BRs.

Oftentimes, success and failure come from an issue that needs to be addressed within a society (e.g., how one culture views protected area sites). Studies that compare sites from different countries and cultures allow the core factors of the sites to be compared. From this study, it was determined that the designation of the site alone does not ensure community engagement. Not only awareness of, but also education about, the roles and economic benefits of the designation are essential.

Further studies should be conducted examining the methods for increasing local involvement and their effects on BRs and GPs in other countries and cultures. There is a need to investigate why some countries have a stronger involvement of local communities in the management process than others, and what obstacles are impeding the involvement of local communities in the local activities inside BRs and GPs. There should also be further investigation into the different roles of the communities that are involved and how those roles directly affect the success of the site. Finding other reasons for community involvement in BRs and UGGps is key for all UNESCO designated sites.

Author Contributions: A.M. conducted the principal investigation inside both counties, conducted the literature review, conducted informal interviews for local communities and officials, and wrote and drafted the entire article; A.R. provided the materials on the Russian AGP and wrote some parts of Sections 2.1.4 and 3.2; T.B. provided the materials on the Russian ABR and wrote some parts of Sections 2.1.3 and 3.2; C.D.S. revised and edited the manuscript, consulted with the authors about the 
manuscript's revised structure and contents, and included the conclusion. All authors have read and agreed to the published version of the manuscript.

Funding: This study was financed by the Japanese Grants-in-Aid for Scientific Research KAKENHI 19K13908.

Informed Consent Statement: Informed consent was obtained from all subjects involved in the study.

Data Availability Statement: All data is stored at Kanazawa University, and is available from the corresponding author on reasonable request.

Conflicts of Interest: The authors declare no conflict of interest.

\section{References}

1. UNESCO. International Geoscience and Geoparks Programme (IGGP). Available online: https://en.unesco.org/internationalgeoscience-and-geoparks-programme (accessed on 23 November 2021).

2. UNESCO. Man and Biosphere Programme. Available online: https://en.unesco.org/mab (accessed on 23 November 2021).

3. UNESCO. Biosphere Reserves. Available online: https://en.unesco.org/biosphere (accessed on 23 November 2021).

4. Batisse, M. Biosphere reserves: A challenge for biodiversity conservation \& regional development. Environ. Sci. Policy Sustain. Dev. 1997, 39, 6-33.

5. UNESCO. Biosphere Reserves: "The Seville Strategy \& the Statutory Framework of the World Network" Paris. 1996. Available online: http:/ / unesdoc.unesco.org/images/0010/001038/103849Eb.pdf (accessed on 26 November 2021).

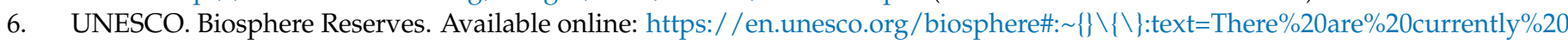
701\%20biosphere,World\%20Network\%20of\%20Biosphere\%20Reserves (accessed on 15 November 2020).

7. EGN European Geopark Charter. European Geoparks Network. Available online: http://www.europeangeoparks.org/?page_ $\mathrm{id}=357$ (accessed on 23 November 2021).

8. Jones, C. History of geoparks. Geol. Soc. Lond. Spec. Publ. 2008, 300, 273-277. [CrossRef]

9. UNESCO. Global Geoparks. Available online: http://www.unesco.org/new/en/natural-sciences/environment/earth-sciences/ unesco-global-geoparks /list-of-unesco-global-geoparks / (accessed on 18 October 2021).

10. Schaaf, T.; Diana, C.R. Managing MIDAs: Harmonising the Management of Multi-Internationnaly Designated Areas: Ramsar Sites, World Heritage Sites, Biosphere Reserves and UNESCO Global Geoparks; IUCN International Union for Conservation of Nature and Natural Resources: Gland, Switzerland, 2016.

11. Price, M.F. The periodic review of biosphere reserves: A mechanism to foster sites of excellence for conservation and sustainable development. Environ. Sci. Policy 2002, 5, 13-18. [CrossRef]

12. Stoll-Kleemann, S.; Bender, S.; Berghöfer, A.; Bertzky, M.; Fritz-Vietta, N.; Schliep, R.; Thierfelder, B. Linking governance and management perspectives with conservation success in protected areas and biosphere reserves. Perspect. Biodivers. Gov. Manag. 2006, 1, 40 .

13. Azman, N.; Halim, S.A.; Liu, O.P.; Saidin, S.; Komoo, I. Public education in heritage conservation for geopark community. Procedia Soc. Behav. Sci. 2010, 7, 504-511. [CrossRef]

14. Aoki, T.; Hibino, T. Joint Management of Geopark and Biosphere Reserve: The Case Study in the Hakusan Tedorigawa National Geopark in Japan. In Proceedings of the 6th International UNESCO Conference on Global Geoparks 2014 Abstracts, Yokohama, Japan, 28 April-2 May 2014.

15. United Nations Sustainable Development Goals. Available online: https://sdgs.un.org/goals (accessed on 23 November 2021).

16. Catana, M.; Brilha, J.B. The role of UNESCO Global Geoparks in promoting geosciences education for sustainability. Geoheritage 2020, 12, 1. [CrossRef]

17. Conley, A.; Moote, M.A. Evaluating collaborative natural resource management. Soc. Nat. Resour. 2003, 16, 371-386. [CrossRef]

18. Farsani, N.T.; Coelho, C.; Costa, C. Geotourism and geoparks as novel strategies for socio-economic development in rural areas. Int. J. Tour. Res. 2011, 13, 68-81. [CrossRef]

19. McKeever, P. UNESCO Global Geoparks and Agenda 2030. In Proceedings of the 8th International Conference on UGGps: Geoparks and Sustainable Development. Adamello Brenta UNESCO Global Geopark, Madonna di Campiglio, Italy, 8-14 September 2018; p. 22.

20. Mammadova, A.; Smith, C.D.; Yashina, T. Comparative Analysis between the Role of Local Communities in Regional Development inside Japanese and Russian UNESCO's Biosphere Reserves: Case Studies of Mount Hakusan and Katunskiy Biosphere Reserves. Sustainability 2021, 13, 10422. [CrossRef]

21. McNeely, J.A. Protected areas for the 21st century: Working to provide benefits to society. Biodivers. Conserv. 1994, 3, 390-405. [CrossRef]

22. Price, M.F.; Park, J.J.; Bouamrane, M. Reporting progress on internationally designated sites: The periodic review of biosphere reserves. Environ. Sci. Policy 2010, 13, 549-557. [CrossRef]

23. Adams, W.C. Conducting semi-structured interviews. In Handbook of Practical Program Evaluation, 4th ed.; Hatry, H.P., Wholey, J.S., Newcomer, K.E., Eds.; Jossey-Bass a Wiley Imprint: San Francisco, CA, USA, 2015; pp. 492-505.

24. Mount Hakusan Biosphere Reserve, Japan. Available online: https://en.unesco.org/biosphere/aspac/mount-hakusan (accessed on 25 January 2022). 
25. Iida, Y.; Nakamura, S. Mount Hakusan Biosphere Reserve: Creating a New Path for Communities and Nature; UNU-IAS OUIK: Kanazawa, Japan, 2016; p. 116.

26. Hakusan City Homepage. Available online: http://www.city.hakusan.ishikawa.jp/otherdata/language/en/about_hakusan_city. html (accessed on 12 August 2021). (In Japanese).

27. UNESCO. MAB Seville Strategy Biosphere Reserves: The Seville Strategy and the Statutory Framework of the World Net-Work; UNESCO: Paris, France. Available online: http:/ / www.mab.cas.cn/ryswqjh/swqbhq/201411/W020141113678526165131.pdf (accessed on 15 January 2021).

28. Hakusan Tedorigawa, Japan. Geographical and Geological Summary. Available online: http://www.globalgeopark.org.cn/ UploadFiles/2021_3_9/intergov_check_english_2021.pdf (accessed on 25 January 2022).

29. Kuwajima Fossil Bluff. Available online: https://hakusan-geo.jp/en/area/281/ (accessed on 25 January 2022).

30. Altai Nature Reserve, Important Bird Areas. Available online: https://www.tourcounsel.com/2021/05/altai-nature-reserverussia.html (accessed on 25 January 2022).

31. Akimova, T.; Kalmykov, I. Altai Biosphere Reserve and the realization of "The Lima plan". In Proceedings of the VIII International Scientific and Practical Conference. Biosphere facilities and sustainable rural development, Irkutsk, Russia, 8-10 October 2018; pp. 32-42. (In Russian)

32. Kocheeva, N.A.; Iurkova, N.A.; Sukhova, M.G.; Redkin, A.G.; Zhuravleva, O.V. Geospatial potential and environmental changes: Case study of complex nature of the Altai Geopark. J. Water Land Dev. 2021, 49, 273-281.

33. Mount Hakusan Tedori-River Geopark. Available online: https://hakusan-geo.jp/ (accessed on 23 November 2021).

34. Kalmykov, I.; Shigreva, S.; Akimova, T.; Trifanova, S.; Samohvalova, O. Altaisky biosphere reserve: Results of the decade. Probl. Geogr. 2021, 153, 407-434. (In Russian) [CrossRef]

35. Korf, E.D. Geopark Altai. Obshestvo. Sreda. Razvitiye Terra Humana 2017, 2, 4. Available online: http://oaji.net/articles/2017/463 8-1510662618.pdf (accessed on 12 December 2021). (In Russian)

36. Hiwasaki, L. Community-based tourism: A pathway to sustainability for Japan's protected areas. Soc. Nat. Resour. 2006, 19, 675-692. [CrossRef]

37. NACS-J (Nature Conservation Society of Japan). Yutakana Shizen, Fukai Fureai, Patonashippu—21 Seiki no Kokuritsukoen no Ari-kata wo Kangaeru (Rich Nature, Deep Interactions, and Partnership: Considering National Parks in the 21st Century); NACS-J: Tokyo, Japan, 2000; p. 88.

38. Usuki, M. Present state and perspectives on national parks and protected areas in South-East Asian region. Tropics 2004, 13, 221-232. [CrossRef]

39. Woo, H. Balancing Conservation and Development in National Parks of Japan: Success or Failure? J. Korean Environ. Sci. Soc. 1995, 4, 303-315.

40. Watanabe, M. Moving toward geopark activities in Japan. Chiri 2008, 53, 26-31. (In Japanese)

41. Watanabe, M. Recent activities of the Japanese Geoparks Network. In Proceedings of the 9th European Geoparks Conference, Lesvos Island, Greece, 1-5 October 2010; Volume 25.

42. Koizumi, T.; Chakraborty, A. Geoecotourism and environmental conservation education: Insights from Japan. GeoJournal 2016, 81, 737-750. [CrossRef]

43. Mammadova, A. Integrating Japanese Local Government and Communities into the Educational Curriculum on Regional Sustainability Inside the UNESCO's Biosphere Reserves and Geoparks. Sustainability 2021, 13, 2497. [CrossRef]

44. Kikuchi, T.; Iwata, S.; Watanabe, M.; Matsumoto, J.; Koide, H. An Overview: Special Issue on "Geoparks and Regional Development". J. Geogr. Chigaku Zasshi 2011, 120, 725-728. (In Japanese) [CrossRef]

45. Watanabe, M. Global geoparks network and geoparks in Japan. J. Geogr. Chigaku Zasshi 2011, 120, 733-742. [CrossRef]

46. Weiner, D.R. Models of Nature: Ecology, Conservation, and Cultural Revolution in Soviet Russia; University of Pittsburgh Press: Pittsburgh, PA, USA, 2000.

47. Ostergren, D.; Shvarts, E. Russian zapovedniki in 1998: Recent progress and new challenges for Russia's strict nature preserves. Proc. RMRS 1998, 14, 209

48. Ostergren, D.M.; Hollenhorst, S.J. Convergence in protected area policy: A comparison of the Russian zapovednik and American wilderness systems. Soc. Nat. Resour. 1999, 12, 293-313.

49. Federal Law about the Specially Protected Natural Areas (Federalnie Zakon ob Osobo Okhranyaemikh Prirodnikh Terri-toriyakh). Ekos Inform. Available online: http:/ / www.consultant.ru/document/cons_doc_LAW_6072/48e0e85bf1393f43721754f9c3253a7 ccded30a4/ (accessed on 12 January 2021). (In Russian)

50. All-Russian Research Geological Institute Named after V.I. A.P. Karpinsky VSEGE. Available online: http://www.vsegei.com/ $\mathrm{ru} /$ about/history/1882-1917/index.php (accessed on 12 January 2022).

51. Semenov, Y.M.; Babin, V.G.; Kocheeva, N.A.; Shitov, A.V.; Zhuravleva, O.V.; Minaev, A.I.; Sukhova, M.G. Ekologichesky Orientirovannoe Planirovanie Zemlepolzovaniya v Altaiskom Regione. Kosh-Agachskiy Raion [Ecologically Oriented Land Use Planning in the Altai Region. Kosh-Agach District]; Geo Acad. Press: Novosibirsk, Russia, 2003; Volume 5, p. 131. (In Russian)

52. Project to Create a Geopark in the Altai Republic. Available online: https://tass.ru/sibir-news/7507201 (accessed on 25 January 2022). (In Russian) 